\title{
Effect of Organic Amendments on Sclerotial Germination, Mycelial Growth, and Sclerotium rolfsii-Induced Diseases
}

\author{
Luiz E. B. Blum ${ }^{1}$ \& Rodrígo Rodríguez-Kábana ${ }^{2}$ \\ ${ }^{1}$ Universidade de Brasília, Departamento de Fitopatologia, Brasília, DF, Brazil, CEP 70910-900, e-mail: luizblum@unb.br; \\ ${ }^{2}$ Auburn University, Dept. Plant Pathology, 209 Life Sciences Building, Auburn AL USA 36849
}

(Aceito para publicação em 26/09/2003)

Corresponding author: Luiz Eduardo B. Blum

BLUM, L.E.B. \& RODRÍGUEZ-KÁBANA, R. Effect of soil organic amendments on sclerotial germination, mycelial growth, and Sclerotium rolfsii-induced diseases. Fitopatologia Brasileira 29:066-074. 2004.

\begin{abstract}
The addition of organic residues to soil is an option to control some soil-borne diseases. Benzaldehyde and powders of kudzu (Pueraria lobata), velvetbean (Mucuna deeringiana), and pine-bark (Pinus elliottii and P. taeda) added to soil could reduce certain soilborne diseases. This study evaluated the effects of benzaldehyde and the dried powders of kudzu, velvetbean, and pine-bark as soil amendments on germination and formation of sclerotia, on mycelial growth of Sclerotium rolfsii, on plant survival, and disease incidence. The data showed that high amounts of benzaldehyde $\left(0.4 \mathrm{ml} \mathrm{kg}^{-1}\right.$ of soil) and velvetbean $\left(100 \mathrm{~g} \mathrm{~kg}^{-1}\right)$ inhibited $S$. rolfsii mycelial growth and sclerotium germination. However, low amounts of benzaldehyde $\left(0.1 \mathrm{ml} \mathrm{kg}{ }^{-1}\right), \mathrm{kudzu}\left(25 \mathrm{~g} \mathrm{~kg}^{-1}\right)$, and pine-bark $\left(25 \mathrm{~g} \mathrm{~kg}^{-1}\right)$ stimulated mycelial growth and sclerotium germination. Kudzu (25-100 $\left.\mathrm{g} \mathrm{kg}^{-1}\right)$ and velvetbean (25-100 $\left.\mathrm{g} \mathrm{kg}^{-1}\right)$ inhibited the formation of sclerotia.

Nevertheless, benzaldehyde at 0.2 and $0.4 \mathrm{ml} \mathrm{kg}^{-1}$ stimulated the formation of sclerotia. Kudzu (50 and $100 \mathrm{~g} \mathrm{~kg}^{-1}$ ) and pine-bark (50 $\mathrm{g} \mathrm{kg}^{-1}$ ) favored the colonization of sclerotia by Trichoderma sp. The numbers of soybean (Glycine max) plants were higher and diseased plants were lower than the non-amend soil in the following treatments: kudzu (50 and $100 \mathrm{~g} \mathrm{~kg}^{-1}$ ), velvetbean (50 and $100 \mathrm{~g} \mathrm{~kg}^{-1}$ ), and pinebark $\left(50 \mathrm{~g} \mathrm{~kg}^{-1}\right)$. Disease severity on tomato (Lycopersicon esculentum) plants was low in soil treated with kudzu or velvetbean (30 and 35 $\left.\mathrm{g} \mathrm{kg}^{-1}\right)$ and pine-bark $\left(35 \mathrm{~g} \mathrm{~kg}^{-1}\right)$. Dried powders of kudzu, velvetbean, or pine-bark added to soil can reduce disease by reducing pathogen inoculum.

Additional keywords: Glycine max, Lycopersicon esculentum, Mucuna deeringiana, Pueraria lobata, velvetbean, biocontrol, and suppressive soils.
\end{abstract}

\section{RESUMO}

Efeitos de resíduos orgânicos no solo na germinação de esclerócios, no crescimento micelial e na ocorrência de doenças induzidas por Sclerotium rolfsii

A adição ao solo de resíduos orgânicos é uma opção para o manejo de doenças causadas por patógenos de solo. Benzaldeido e resíduos moídos de puerária (Pueraria lobata), mucuna (Mucuna deeringiana) e casca de Pinus (Pinus elliottii e $P$. taeda) podem reduzir certas doenças propagadas pelo solo. Este estudo avaliou os efeitos do benzaldeido e de pós-secos de puerária, mucuna e casca de Pinus sp. como resíduos de solo na germinação e formação de esclerócios, no crescimento micelial de Sclerotium rolfsii, na sobrevivência de plantas, na incidência de doença e na atividade enzimática do solo. Concentrações mais altas de benzaldeido $\left(0,4 \mathrm{ml} \mathrm{kg}^{-1}\right.$ de solo $)$ e mucuna $\left(100 \mathrm{~g} \mathrm{~kg}^{-1}\right)$ inibiram o crescimento micelial e a germinação de esclerócios.

\section{INTRODUCTION}

The management of soil-borne plant pathogens is particularly complex because these organisms live in or near the dynamic environment of the rhizosphere, and can frequently survive long periods in soil through the formation of resistant survival structures. Soil-borne pathogens are responsible for crop yield losses in many plants.

Sclerotium rolfsii Sacc. [Athelia rolfsii (Curzi) Tu \& Kimbrough] causes the disease known as southern blight in a
Todavia, concentrações mais baixas de benzaldeido $\left(0,1 \mathrm{~g} \mathrm{~kg}^{-1}\right)$, puerária ( $\left.25 \mathrm{~g} \mathrm{~kg}^{-1}\right)$, e casca de Pinus sp. $\left(25 \mathrm{~g} \mathrm{~kg}^{-1}\right)$ estimularam o crescimento micelial e a germinação de esclerócios. Puerária $\left(25-100 \mathrm{~g} \mathrm{~kg}^{-1}\right)$ e mucuna (25-100 $\left.\mathrm{g} \mathrm{kg} \mathrm{g}^{-1}\right)$ inibiram a formação de esclerócios. Contudo, benzaldeido a 0,2 e $0,4 \mathrm{ml} \mathrm{kg}^{-1}$ estimulou a formação de esclerócios. Puerária (50 e $\left.100 \mathrm{~g} \mathrm{~kg}^{-1}\right)$ e casca de Pinus sp. $\left(50 \mathrm{~g} \mathrm{~kg}^{-1}\right)$ favoreceram a colonização dos esclerócios por Trichoderma sp. O número de plantas de soja (Glycine max) foi maior e o número de plantas doentes foi mais baixo em solos com puerária (50 e $\left.100 \mathrm{~g} \mathrm{~kg}^{-1}\right)$, mucuna $\left(50 \mathrm{e} 100 \mathrm{~g} \mathrm{~kg}^{-1}\right)$ e casca de Pinus sp. $\left(50 \mathrm{~g} \mathrm{~kg}^{-1}\right)$ do que em solos sem estes resíduos. A severidade de doença em tomateiro (Lycopersicon esculentum) foi baixa em solo com puerária ou mucuna (30 e $35 \mathrm{~g} \mathrm{~kg}^{-1}$ ) e casca de Pinus sp. ( $\left.35 \mathrm{~g} \mathrm{~kg}^{-1}\right)$. Pós-secos de puerária, mucuna ou casca de Pinus sp. incorporados ao solo podem reduzir a doença devido à redução do inóculo do patógeno.

wide variety of crops. Sclerotium rolfsii forms brownish sclerotia that can survive in soil for long periods, frequently tolerating biological and chemical degradation due to the presence of melanin in the outer membrane (Chet, 1975). Among the methods employed to manage $S$. rolfsii are the following: fungicide applications, solarization, use of antagonistic microorganisms, deep plowing, crop rotation, and incorporation of organic and inorganic residues (Punja, 1985). Organic matter added to soil may increase soil fertility, stimulate growth of crops, and suppress plant pathogens. When properly used, 
Effect of soil organic amendments on sclerotial germination, mycelial growth...

amendments can not only reduce populations of soil-borne pathogens but also induce soil suppressiveness by stimulating activities of antagonists in soil. Enhancing numbers of antagonists in soil generally leads to a decrease in viable pathogen inoculum and a reduced need for fungicides (Linderman, 1989; Gamliel \& Stapleton, 1993).

Some amendments suppress and others stimulate sclerotium germination in soil (Beute \& Rodríguez-Kábana, 1979). Germinated sclerotia are much more susceptible to antagonists than viable non-germinated ones (Smith, 1972). Non-germinated sclerotia can have their viability decreased by some amendments, thus becoming more sensitive to antagonistic action by other microorganisms (Hadar \& Gorodecki, 1991).

In this study dried powders of velvetbean [Mucuna deeringiana (Bort) Small], kudzu [Pueraria lobata (Willd.) Ohivi], and pine (Pinus spp.) and purified benzaldehyde [aromatic compound, extracted from bitter almond (Prunus amygdalus Batsch.)] were evaluated as amendments to soil. These amendments can result in the suppression of nematodes and other soil-borne pathogens (Rodríguez-Kábana et al., 1992; Kokalis-Burelle \& Rodríguez-Kábana, 1994). Used at low rates, benzaldehyde can act as a spore germination-inducing agent, can stimulate and select for biological control microorganisms against $S$. rolfsii, and can act as a fungicidal or fungistatic compound when used at high concentrations (Soler-Serratosa et al., 1996).

Some research has been done on the effects of temperature, moisture, $\mathrm{pH}$, salinity, fungicides, amendments, and volatile compounds on the germination of $S$. rolfsii sclerotia (Beute \& Rodríguez-Kábana, 1981; Maiti \& Sen, 1988; Canullo et al., 1992). However, there is limited information available on the effect of benzaldehyde, kudzu, velvetbean, and pine bark on the sclerotial germination and mycelium growth of $S$. rolfsii on soil.

The objective of this study was to evaluate the effect of benzaldehyde, kudzu, velvetbean, and pine bark powder as organic amendments on the germination of $S$. rolfsii sclerotia and on $S$. rolfsii inoculi colonization by Trichoderma spp., on mycelial growth and formation of new sclerotia, on plant survival and disease incidence, and on shifts of soil microbial activities by means of soil enzyme activity measurements.

\section{MATERIALS AND METHODS}

Sclerotium rolfsii was isolated from diseased tomato (Lycopersicon esculentum Mill.) plants. The fungus was maintained at room temperature $\left(20-25^{\circ} \mathrm{C}\right)$ in test tubes with malt extract agar medium. Sclerotium rolfsii colonized oat (Avena sativa L.) seeds were used as inoculum for soil infestation and production of soil sclerotia (Punja \& Rahe, 1992).

The soil used for laboratory and greenhouse experiments was a sieved ( $2 \mathrm{~mm}$ ) sandy-soil mixed with siliceous river sand $(50: 50 \mathrm{w} / \mathrm{w})$. The soil was collected from a peanut (Arachis hypogaea L.) field at the Auburn University campus experimental farm in Auburn, Alabama. The elemental composition and other characteristics of the soil is presented here (Auburn University Soil Testing Laboratory): Marvin sandy loam (Typic kanhapludults), CEC $<4.6 \mathrm{cmol} \mathrm{kg}^{-1}, \mathrm{pH} 6.8$, $\mathrm{C} 0.65 \%$, N $0.04 \%$, P $19.5 \mathrm{mg} \mathrm{kg}^{-1}, \mathrm{~K} 38.0 \mathrm{mg} \mathrm{kg}^{-1}, \mathrm{Mg} 65.0 \mathrm{mg}$ $\mathrm{kg}^{-1}$, and $\mathrm{Ca} 300.0 \mathrm{mg} \mathrm{kg}^{-1}$.

Commercially available pine bark nuggets (mixture of Pinus elliottii Englem. and P. taeda L. - ProCare Earth Pak Inc.) and approximately three month old kudzu and velvetbean plants (leaves and stems) were used in the experiments. These materials were dried for two weeks on greenhouse benches $\left(25-35^{\circ} \mathrm{C}\right)$, and ground $(<500 \mu \mathrm{m})$ with a Straub Model $4 \mathrm{E}$ Grinding Mill. The ground amendments were maintained in plastic boxes at room temperature until used. The elemental composition of the materials is presented on table 1 . Benzaldehyde $\left(\mathrm{C}_{6} \mathrm{H}_{5} \mathrm{CHO}\right.$ - FW 106.13 - specific gravity 1.04) was obtained from Aldrich Chemical Co.

\section{Effect of amendmets on sclerotial germination, mycelial growth, and colonization of $S$. rolfsii inoculum by Trichoderma} spp.

Two tests with soil-produced sclerotia and two with $S$. rolfsii-colonized oat seeds were performed to evaluate the direct effect of amendments on surface mycelium growth and on sclerotial germination. Treatments consisted of non-amended soil (control), benzaldehyde (0.1, 0.2 , and $\left.0.4 \mathrm{ml} \mathrm{kg}^{-1}\right)$, kudzu, velvetbean, and pine bark powders $\left(25,50\right.$, and $\left.100 \mathrm{~g} \mathrm{~kg}^{-1}\right)$, and an extra control with sterile soil. Materials were thoroughly mixed with soil in polyethylene plastic bags $(20 \times 15 \mathrm{~cm})$ and then five replications of $100 \mathrm{~g}$ samples of each soil mixture were poured into $150 \mathrm{ml}$-plastic cups (Solo Cup Co.). After application of the amendments in soil, all experimental units received $20 \mathrm{ml}$ of sterile water and were thoroughly mixed again. Determinations of sclerotial germination and mycelium growth were made 24 to $72 \mathrm{~h}$ after inoculum deposition on soil. The number of new sclerotia and Trichoderma spp.-colonized sclerotia or oat seeds was assessed three to ten days after inoculation.

Twenty sclerotia were spread $1 \mathrm{~cm}$ apart on the soil surface of each cup. Cups in experiments with $S$. rolfsii colonized oat seeds, received five 1-cm-apart seeds on soil surface / replication (Rodríguez-Kábana et al., 1975a). After the inoculum deposition, the cups were closed with a perforated ( $2 \mathrm{~mm}$ diameter) plastic lid to allow gas exchange. The cups were incubated at $27^{\circ} \mathrm{C}$ (Precision Scientific incubator - GCA Corporation). Cups with soil amended with benzaldehyde were placed in separate plastic boxes with lid covers to avoid gas-contamination cups with other amendments with benzaldehyde vapor. Mycelial growth was evaluated for each sclerotium or seed, 24, 48, and $72 \mathrm{~h}$ after inoculation according to a subjective scale $(1-<1 \mathrm{~mm}$ growth from the sclerotium or seed; $2-1-3 \mathrm{~mm} ; 3->3 \mathrm{~mm})$.

\section{Effect of amendments on soybean (Soybean max L.) and tomato survival}

A set of three experiments was performed under greenhouse conditions to evaluate the efficacy of benzaldehyde $\left(0.1,0.2\right.$, and $\left.0.4 \mathrm{ml} \mathrm{kg}^{-1}\right)$, kudzu $\left(25,50\right.$, and $\left.100 \mathrm{~g} \mathrm{~kg}^{-1}\right)$, 
velvetbean $\left(25,50\right.$, and $\left.100 \mathrm{~g} \mathrm{~kg}^{-1}\right)$ and pine bark powder $(25$, 50 , and $100 \mathrm{~g} \mathrm{~kg}^{-1}$ ) on soybean ('Davis') survival. One day before application of the amendments to soil, $5 \mathrm{~g}$ of $S$. rolfsiii colonized oat seeds were mixed with $1 \mathrm{~kg}$ of natural soil contained in 1 liter capacity 10-cm-diameter cylindrical PVC pots (experimental unit). Treatments with sterile and natural soil, with and without the pathogen, were also included. Experiments were arranged in a completely randomized design, with 16 treatments and five or six replications of ten plants.

At the time of soil infestation and application of the amendments in soil the contents of each pot was poured into polyethylene plastic bags $(30 \times 20 \mathrm{~cm})$ and thoroughly mixed. The only difference in procedures among experiments was in the time of sowing. Seeds were sown ten, 20 and 40 days after application of the amendments to soil, in the first, second, and third experiments, respectively. These differences in times of sow were used, in order to detect any toxic effects on seed germination due to amendments. The number of plants in each experiment was determined from seven to 21 days after sowing. Each of these tests was done twice.

Experiments with different rates of benzaldehyde, kudzu, velvetbean, and pine bark powder were performed to evaluate the effect of these amendments on tomato ('Rutgers') survival and growth. Ten rates of kudzu, velvet bean and, pine bark powder $\left(0,2.5,5,7.5,10,15,20,25,30\right.$, and $35 \mathrm{~g} \mathrm{~kg}^{-1}$ of soil), and ten rates of belzaldehyde were applied $(0.0,0.1,0.2$, $0.3,0.4,0.5,0.6,0.8,1.0$, and $1.2 \mathrm{ml} \mathrm{kg}^{-1}$ of soil). Soil infestation and application of the amendments to soil were as described for the soybean experiments.

Each treatment was replicated six times and arranged in a randomized complete block design. Two tomato transplants were made, one 30 days and the other 120 days after application of the soil amendments. In the transplantings two 30-day-old tomato plants were used. Enumeration of sclerotia on the soil surface was made 14 days after application of the soil amendments, and disease severity and plant growth evaluations were made at the end of each planting cycle.

\section{Effect of amendments on soil enzyme activity}

For the tomato experiments, samples were collected 30 and 120 days after application of the soil amendments, sieved ( $2 \mathrm{~mm}$ ), and kept at $-10^{\circ} \mathrm{C}$. Measurement of esterase activities was performed by a modification (Soler-Serratosa et al., 1996) of the method described by Schnürer \& Rosswall (1982), based on fluorescein diacetate hydrolysis. Readings were expressed in terms of $\mu \mathrm{g}$ of fluorescein produced $\mathrm{h}^{-1} \mathrm{~g}^{-1}$ soil, based in a previously prepared calibration curve with Fluorescein Na salt (Aldrich Chemical Co. Inc.). Catalase (E.C.1.11.1.6) activity was determined according to Rodríguez-Kábana \& Truelove (1970). Catalase activity was expressed in meq $\mathrm{H}_{2} \mathrm{O}_{2}$ decomposed $\mathrm{h}^{-1}$ $\mathrm{g}^{-1}$ of soil. Controls with and without sterile soil were taken into account for non-biological $\mathrm{H}_{2} \mathrm{O}_{2}$ decomposition

Soil $\mathrm{pH}$ was determined with demineralized water [McLean (1982) modified]. After pH measurement the soil supernatant from each sample was used to determine conductivity $\left(\mu \mathrm{S} \mathrm{cm}^{-1}\right)$ with a conductivity meter (TDS WD-
TABLE 1 - Elemental composition of kudzu (Pueraria lobata), velvetbean (Mucuna deeringiana), and pine bark (Pinus spp.) powders

\begin{tabular}{lrrr}
\hline \hline Elemental composition & Kudzu & Velvetbean & Pine Bark \\
\hline $\mathrm{C}(\%)$ & 44.31 & 45.04 & 51.76 \\
$\mathrm{~N}(\%)$ & 1.38 & 2.60 & 0.22 \\
$\mathrm{C}: \mathrm{N} \mathrm{ratio}$ & 32.11 & 17.32 & 235.27 \\
$\mathrm{P}(\%)$ & 0.06 & 0.26 & 0.02 \\
$\mathrm{~K}(\%)$ & 0.80 & 1.55 & 0.08 \\
$\mathrm{Ca}(\%)$ & 1.08 & 1.23 & 0.21 \\
$\mathrm{Mg}(\%)$ & 0.29 & 0.35 & 0.03 \\
$\mathrm{Cu}\left(\mathrm{mg} \mathrm{kg}^{-1}\right)$ & 1.45 & 20.02 & 0.00 \\
$\mathrm{Fe}\left(\mathrm{mg} \mathrm{kg}^{-1}\right)$ & 308.54 & 498.42 & 94.94 \\
$\mathrm{Mn}\left(\mathrm{mg} \mathrm{kg}^{-1}\right)$ & 49.48 & 219.43 & 73.43 \\
$\mathrm{Zn}\left(\mathrm{mg} \mathrm{kg}^{-1}\right)$ & 11.25 & 20.42 & 12.61 \\
$\mathrm{~B}\left(\mathrm{mg} \mathrm{kg}^{-1}\right)$ & 24.16 & 30.01 & 7.42 \\
$\mathrm{Al}\left(\mathrm{mg} \mathrm{kg}^{-1}\right)$ & 435.45 & 998.73 & 683.81 \\
$\mathrm{Ba}\left(\mathrm{mg} \mathrm{kg}^{-1}\right)$ & 49.86 & 138.42 & 13.06 \\
$\mathrm{Co}\left(\mathrm{mg} \mathrm{kg}^{-1}\right)$ & 0.13 & 2.50 & 1.62 \\
$\mathrm{Cr}\left(\mathrm{mg} \mathrm{kg}^{-1}\right)$ & 1.19 & 2.61 & 0.16 \\
$\mathrm{~Pb}\left(\mathrm{mg} \mathrm{kg}^{-1}\right)$ & 0.00 & 0.25 & 0.00 \\
$\mathrm{Na}\left(\mathrm{mg} \mathrm{kg}^{-1}\right)$ & 97.38 & 185.13 & 7.17 \\
$\mathrm{Mo}\left(\mathrm{mg} \mathrm{kg}^{-1}\right)$ & 1.52 & 2.04 & 0.86 \\
\hline
\end{tabular}

Analyses made by: Soil Testing Laboratory at Auburn University, Auburn, $\mathrm{AL}$

35661-30, Oakton Co.) [Rhoades (1982) modified].

Treatments in the experiments were arranged in a randomized complete block. The data were analyzed by twoway or three-way ANOVA, depending on the objective of the experiment. Differences among averages were evaluated for significance according to Fisher's PLSD test $(\mathrm{P}<0.05)$. Regression or correlation analyses were performed following standard procedures. SigmaStat v. 2 (SPSS / Jandel Scientific Software) and StatView v. 4.53 (Abacus Concepts) were used for processing the data.

\section{RESULTS}

\section{Mycelial growth}

Soil treatments with benzaldehyde at 0.1 and $0.2 \mathrm{ml} \mathrm{kg}^{-1}$, kudzu and pine bark at all rates, and velvet bean at $25 \mathrm{~g} \mathrm{~kg}^{-1}$ stimulated mycelial growth after $24 \mathrm{~h}$ of incubation (Figure 1A). Benzaldehyde at $0.4 \mathrm{ml} \mathrm{kg}^{-1}$ and velvetbean at $100 \mathrm{~g} \mathrm{~kg}^{-1}$ reduced the mycelial growth (Figure $1 \mathrm{~A}$ and $\mathrm{B}$ ). After $48 \mathrm{~h}$, velvet bean (50- $\left.100 \mathrm{~g} \mathrm{~kg}^{-1}\right)$, benzaldehyde $\left(0.4 \mathrm{ml} \mathrm{kg}^{-1}\right)$, and kudzu (50-100 $\left.\mathrm{g} \mathrm{kg}^{-1}\right)$ inhibited mycelial growth. When colonized oat seeds where used as inoculum, benzaldehyde $\left(0.4 \mathrm{ml} \mathrm{kg}^{-1}\right)$ and velvetbean $\left(100 \mathrm{~g} \mathrm{~kg}^{-1}\right)$ once more reduced mycelial growth for $48 \mathrm{~h}$, while kudzu $\left(100 \mathrm{~g} \mathrm{~kg}^{-1}\right)$ and pine bark $\left(100 \mathrm{~g} \mathrm{~kg}^{-1}\right)$ both reduced it for at least $24 \mathrm{~h}$ after incubation (Figure $1 \mathrm{C}$ and D).

\section{Sclerotium germination}

Sclerotium germination was stimulated by benzaldehyde (0.1-0.2 ml kg-1), $24 \mathrm{~h}$ after incubation (Figure 1E). Kudzu and velvetbean $\left(25-50 \mathrm{~g} \mathrm{~kg}^{-1}\right)$ and pine bark $\left(25-100 \mathrm{~g} \mathrm{~kg}^{-1}\right)$ stimulated 
Effect of soil organic amendments on sclerotial germination, mycelial growth...

germination (Figure 1E). Benzaldehyde $\left(0.4 \mathrm{ml} \mathrm{kg}^{-1}\right)$, velvetbean $\left(100 \mathrm{~g} \mathrm{~kg}^{-1}\right)$ reduced germination $24 \mathrm{~h}$ after incubation in both experiments (Figure 1E). Velvetbean (100 $\left.\mathrm{g} \mathrm{kg}^{-1}\right)$ partially inhibited sclerotial germination even $48 \mathrm{~h}$ after incubation (Figure 1F).

\section{Sclerotium formation}

Sclerotium formation from older ones increased in soil amended with benzaldehyde $\left(0.4 \mathrm{ml} \mathrm{kg}^{-1}\right)$, kudzu $\left(100 \mathrm{~g} \mathrm{~kg}^{-1}\right)$, and pine bark $\left(25 \mathrm{~g} \mathrm{~kg}^{-1}\right)$ (Figure $\left.1 \mathrm{G}\right)$. Sclerotium production was different when oat seeds were used as inoculum, where soil amended with benzaldehyde generally induced sclerotium formation, and treatments with kudzu, velvetbean, and pine bark reduced production of sclerotia (Figure 1H).

\section{Sclerotium rolfsii inoculum colonization by Trichoderma spp.}

Numbers of Trichoderma spp. colonies were highest in soils treated with kudzu (50-100 $\left.\mathrm{g} \mathrm{kg}^{-1}\right)$ and pine bark $\left(50 \mathrm{~g} \mathrm{~kg}^{-1}\right)$, from three to ten days after incubation. Velvetbean amendments had no effect on the number of these fungi on $S$. rolfsii inoculum (Figure 1I).

\section{Survival of soybean and tomato plants}

Figure 2 presents data on the percentages of plants and diseased plants, respectively, in soil infested with $S$. rolfsii and sowed with soybean. The percentage of emerged plants was higher in soil amended with kudzu, velvetbean and pine bark (Figure 2A). Numbers of diseased plants (not considering non-germinated seeds) were lower in kudzu, velvetbean, and pine bark amended soil than in non-amended soil (Figure 2B). The percentage of diseased plants was low in treatments with belzaldehyde ( $\left.0.4 \mathrm{ml} \mathrm{kg}^{-1}\right)$, kudzu (25 to $\left.100 \mathrm{~g} \mathrm{~kg}^{-1}\right)$, velvetbean (25-100 $\left.\mathrm{g} \mathrm{kg}^{-1}\right)$, and pine bark (25-100 $\left.\mathrm{g} \mathrm{kg}^{-1}\right)$. Depending on the time of sowing (Figure $2 \mathrm{C}$ and $\mathrm{D}$ ), amendments resulted in different effects, but in general treatments with kudzu, velvetbean and pine bark increased the percentage of emerged plants (Figure 2A), decreased the percentage of diseased plants (Figure 2B), and increased shoot and root weight (Table 2), when planting was done at 40 days after application of the amendments in soil.

\section{Effects of amendments on disease severity, tomato growth, soil enzymatic activities, soil $\mathrm{pH}$, and conductivity}

Eighty days after planting, increasing rates of velvetbean, pine bark, and kudzu tended to reduce disease severity (Figure 3 and Table 2). Benzaldehyde amended soils had few effect on disease severity.

Plant height and weight (shoots and roots) were increased in response to increased rates of applications of velvetbean and kudzu at both planting times, but pine bark and benzaldehyde applications had no effect on these variables (Table 2). Catalase and fluorescein diacetate hydrolysis (FDA) activities at 30 days after application of the amendments increased with increasing amounts of velvetbean, pine bark, kudzu, and benzaldehyde (FDA activities only) (Table 2). At 120 days after application of the amendments enzymatic activities were slightly higher than as the values in 30 days for treatments with velvet bean (for $30 \mathrm{~g} \mathrm{~kg}^{-1}$, the catalase activity increased from 0.327 to 0.334 meq $\mathrm{H}_{2} \mathrm{O}_{2}$ decomposed $\mathrm{h}^{-1} \mathrm{~g}^{-1}$ of soil, and the FDA activities from 4.147 to $6.410 \mu \mathrm{g}$ of fluorescein produced $\mathrm{h}^{-1} \mathrm{~g}^{-1}$ soil). Pine bark amendments resulted in increased catalase and FDA activities. Data on catalase activity for kudzu amendments 120 days (for $30 \mathrm{~g} \mathrm{~kg}^{-1}=0.345$ meq $\mathrm{H}_{2} \mathrm{O}_{2}$ decomposed $\mathrm{h}^{-1} \mathrm{~g}^{-1}$ of soil) after application of the amendments indicated a similar response to the one at 30 days (for $30 \mathrm{~g} \mathrm{~kg}^{-1}=$ 0.347 meq $\mathrm{H}_{2} \mathrm{O}_{2}$ decomposed $\mathrm{h}^{-1} \mathrm{~g}^{-1}$ of soil), but FDA activity values were significantly $(\mathrm{P}<0.05)$ higher (for $30 \mathrm{~g} / \mathrm{kg}=4.559$ $\mu \mathrm{g}$ of fluorescein produced $\mathrm{h}^{-1} \mathrm{~g}^{-1}$ soil) than the control (1.369 $\mu \mathrm{g}$ of fluorescein produced $\mathrm{h}^{-1} \mathrm{~g}^{-1}$ soil). Catalase activities, in treatments with benzaldehyde $\left(0.1,0.4,0.8\right.$ to $\left.1.2 \mathrm{ml} \mathrm{kg}^{-1}\right)$, were different (for $0.1 \mathrm{ml} / \mathrm{kg}=0.206 \mathrm{meq}_{2} \mathrm{O}_{2}$ decomposed $\mathrm{h}^{-1} \mathrm{~g}^{-1}$ of soil) from the control ( 0.111 meq $\mathrm{H}_{2} \mathrm{O}_{2}$ decomposed $\mathrm{h}^{-1} \mathrm{~g}^{-1}$ of soil) at 30 days after application of the amendments.

Soil $\mathrm{pH}$ tended to increase with the rate of amendment used in the case of velvetbean, kudzu, and benzaldehyde, while the opposite was observed with pine bark amendments (Table 2). For velvetbean and kudzu, conductivity tended to increase in proportion with the rate of amendment applied (Table 2).

Benzaldehyde dosages were positively correlated with plant height and shoot weight, and negatively correlated with FDA activity at 30 days after application of the amendments. Kudzu rates were positively correlated with plant height, shoot weight, root weight, catalase and FDA activities, and soil $\mathrm{pH}$ and conductivity, but negatively correlated to disease severity. Velvetbean rates were negatively correlated with disease severity and number of surface sclerotia, but positively correlated with plant height, shoot weight, root weight, catalase and FDA activities, soil $\mathrm{pH}$ and conductivity. Thirty days after application, pine bark rate was negatively correlated with disease severity, number of surface sclerotia, and soil $\mathrm{pH}$, but positively correlated with root weight (2nd planting), catalase and FDA activities, and conductivity (Table 2).

\section{DISCUSSION}

It is necessary to study the effects of amendments on sclerotial germination and mycelial growth of $S$. rolfsii. This knowledge helps identify some of the reasons for success or failure of amendments to control this fungus. Our results clearly indicate that stimulation of mycelial growth by $S$. rolfsii varies with the type of inoculum (colonized seeds or sclerotia). Previous studies (Beute \& Rodríguez-Kábana, 1979) showed the stimulation of mycelial growth induced by kudzu residues. These authors concluded that stimulation was due to the liberation of volatile compounds released by decomposition of kudzu fragments. In our studies, germination of sclerotia was similarly stimulated by the lowest rates of amendments.

The highest rates of benzaldehyde and velvetbean inhibited mycelial growth and germination of sclerotia of $S$. rolfsii for at least $24 \mathrm{~h}$ after inoculum incubation. Flor (1926) found that benzaldehyde at high rates was fungistatic or fungicidal. Sclerotial germination is a critical stage of the $S$. 
L.E.B. Blum \& R. Rodíguez-Kábana
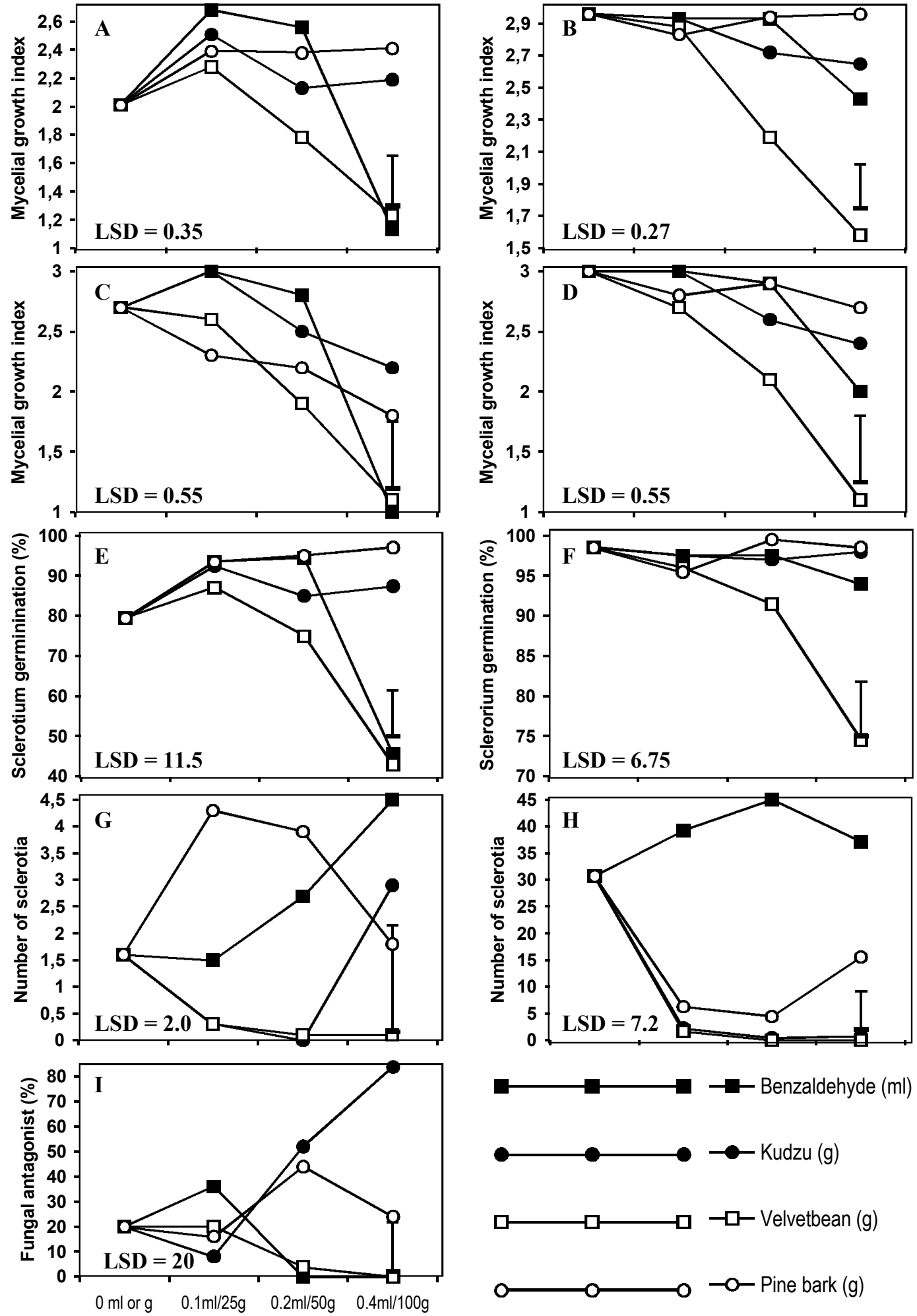

FIG. 1 - Effect of amounts [in $\mathrm{ml} / \mathrm{kg}$ for benzaldehyde and $\mathrm{g} / \mathrm{kg}$ for kudzu (Pueraria labata), velvetbean (Mucuna deeringiana) or pine bark (Pinus spp.)] of amendments on Sclerotium rolfsii mycelial growth from germinated sclerotia (A and B) and from oat seed inoculum (C and D), on sclerotial germination (E and F), 24 (A, C and E) and $48 \mathrm{~h}$ (B, D and F) after incubation, on formation of new sclerotia from older ones $(\mathrm{G})$ and from oat seed inoculum $(\mathrm{H})$, and on formation of colonies (I) of Trichoderma spp. on S. rolfsii inoculum. Data represent an average of two tests. Bar $=\mathrm{LSD}=$ Fisher's least significant difference $(\mathrm{P}=5 \%)$. 
Effect of soil organic amendments on sclerotial germination, mycelial growth...
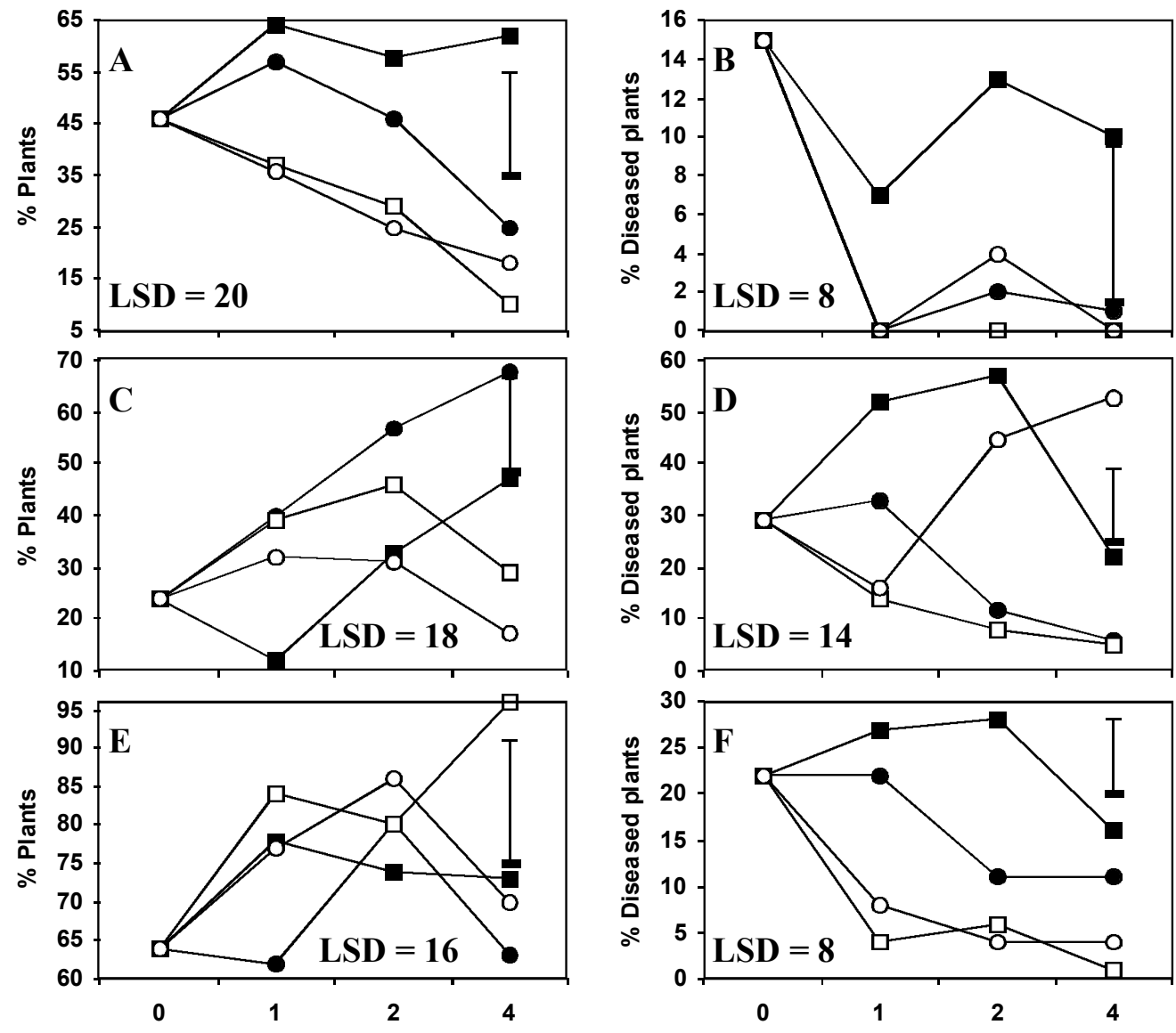

Amount of amendment
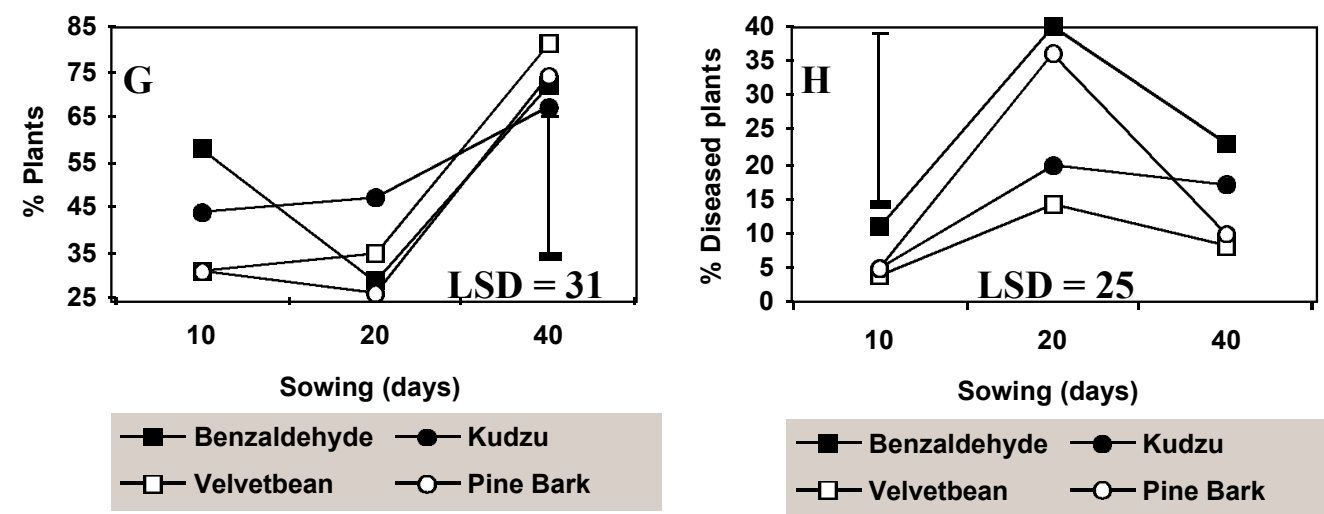

FIG. 2 (A-H) - Percentage of survival and diseased soybean (Glycine max) plants, 14 days after sowing, in soil infested with Sclerotium rolfsii and treated with organic amendments. In (A) through (F) the axis values correspond to amount of soil organic amendments $[0,1,2$, and 4 represent for benzaldehyde $0,0.1,0.2$, and $0.4 \mathrm{ml} / \mathrm{kg}$ of soil, and for kudzu (Pueraria labata), velvetbean (Mucuna deeringiana) or pine bark (Pinus spp.) 0, 25, 50, and $100 \mathrm{~g} / \mathrm{kg}$ of soil]. In (G) and (H) the axis values correspond to time of sowing after soil treatment. Figures (A) and (B) represent data for sowing time of ten days after soil treatment. Figures (C) and (D) represent data for sowing 20 days after soil treatment. Figures (E) and (F) represent data for sowing 40 days after soil treatment. Data represent an average of two experiments. Bar $=$ LSD $=$ Fisher's least significant difference $(\mathrm{P}=5 \%)$.

rolfsii cycle. Delay or inhibition of sclerotial germination and reduction of sclerotial viability by antagonists, decreases both the inoculum potential of the fungus and disease incidence.
Rodríguez-Kábana et al. (1987) demonstrated reduction of sclerotial germination with increasing rates of chitin in soil, and attributed, in part, this reduction to the action of 
L.E.B. Blum \& R. Rodíguez-Kábana

TABLE 2 - Correlation matrixes for amendment rates and parameters measured in soil infested with Sclerotium rolfsii and planted with tomato (Lycopersicon esculentum) cv. Rutgers

\begin{tabular}{|c|c|c|c|c|}
\hline Amendment rate $x$ & Benzaldehyde & Kudzu & Velvetbean & Pine bark \\
\hline Disease Severity $80 \mathrm{~d}^{1}$ & n.s. ${ }^{2}$ & $-0.351 * *^{3}$ & $-0.295^{* 3}$ & $-0.332 * *$ \\
\hline Disease Severity $100 \mathrm{~d}^{1}$ & n.s. & $-0.365^{* *}$ & $-0.342 *$ & $-0.328 *$ \\
\hline No. Surface Sclerotium ${ }^{4}$ & n.s. & n.s. & $-0.514 * * * 3$ & $-0.411 * * *$ \\
\hline Plant height $1^{\text {st }} \mathrm{pl}$ & n.s. & $0.324^{*}$ & $0.331 * *$ & n.s. \\
\hline Shoot weight $1^{\mathrm{st}} \mathrm{pl}$. & n.s. & $0.514 * * *$ & $0.722 * * *$ & n.s. \\
\hline Root weight. $1^{\text {st }}$ pl. & n.s. & $0.406 * * *$ & $0.554 * * *$ & n.s. \\
\hline Plant height $2^{\text {nd }} \mathrm{pl}$. & $0.284 *$ & $0.761 * * *$ & $0.609 * * *$ & n.s. \\
\hline Shoot weight $2^{\text {nd }} \mathrm{pl}$. & $0.294 *$ & $0.767 * * *$ & $0.790 * * *$ & n.s. \\
\hline Root weight $2^{\text {nd }} \mathrm{pl}$. & n.s. & $0.632 * * *$ & $0.628 * * *$ & $0.256^{*}$ \\
\hline Catalase $(30 \mathrm{~d})^{5}$ & n.s. & $0.828^{* * *}$ & $0.811 * * *$ & n.s. \\
\hline Catalase $(120 \mathrm{~d})$ & n.s. & $0.922 * * *$ & $0.915 * * *$ & $0.630 * * *$ \\
\hline FDA $=$ Esterase $(30 d)^{6}$ & $-0.517 * * *$ & $0.568 * * *$ & $0.830 * * *$ & $0.489 * * *$ \\
\hline $\operatorname{FDA}(120 \mathrm{~d})$ & $0.273^{*}$ & $0.700 * * *$ & $0.899 * * *$ & $0.575 * * *$ \\
\hline Conductivity (30 d) & n.s. & $0.913 * * *$ & $0.933 * * *$ & $0.301^{*}$ \\
\hline Conductivity (120d) & n.s. & $0.827 * * *$ & $0.881 * * *$ & n.s. \\
\hline $\mathrm{pH}(30 \mathrm{~d})$ & $-0.659 * * *$ & $0.942 * * *$ & $0.843 * * *$ & $-0.912 * * *$ \\
\hline $\mathrm{pH}(120 \mathrm{~d})$ & n.s. & $0.961 * * *$ & $0.963 * * *$ & $-0.883 * * *$ \\
\hline
\end{tabular}

${ }^{1}$ Disease severity $\left(80\right.$ and $100 \mathrm{~d}$ after tomato second planting); ${ }^{2}$ n.s. $=$ no statistical difference; ${ }^{*}$ significance at $5.0 \% ; * *$ at $1.0 \%$; and ${ }^{* * *}$ at $0.1 \%$; ${ }^{4}$ No. Surface Sclerot. $=$ Number of surface sclerotium formed $14 \mathrm{~d}$ after soil treatment; ${ }^{5} 30$ and $120 \mathrm{~d}=30$ and $120 \mathrm{~d}$ after soil treatment; ${ }^{6}$ Esterase like enzymes expressed by fluorescein diacetate hydrolysis (FDA) activities.

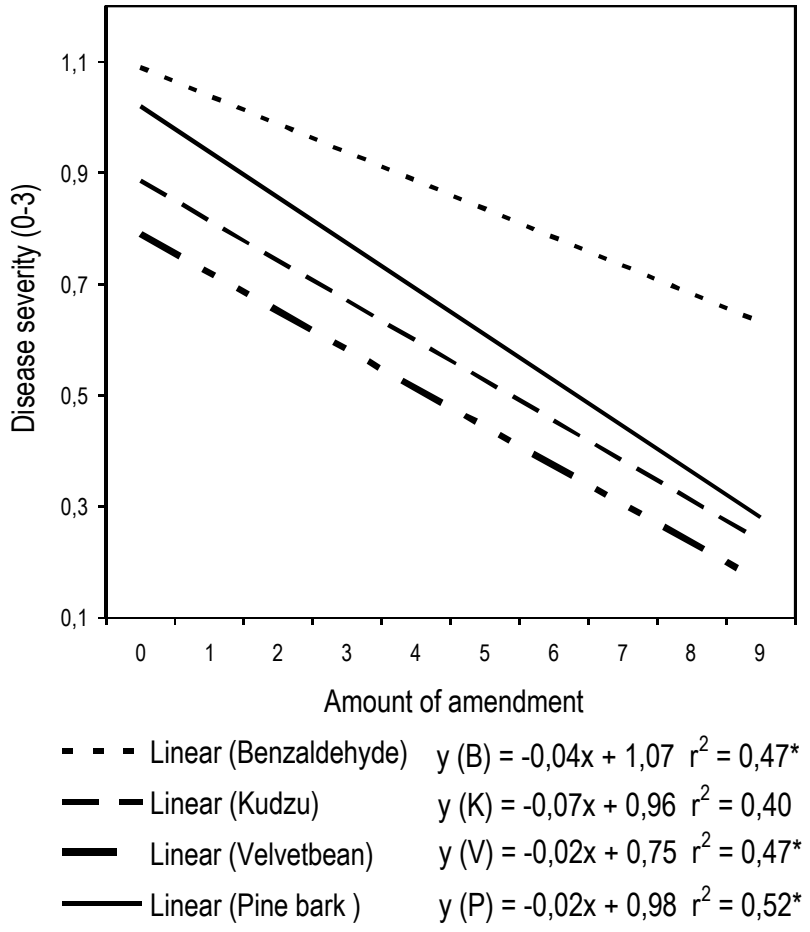

FIG. 3 - Effect of amount of soil organic amendments $[0,1,2,3,4,5$, $6,7,8,9$ represent for benzaldehyde $0,0.1,0.2,0.3,0.4,0.5,0.6,0.8$, 1.0 , and $1.2 \mathrm{ml} \mathrm{kg}^{-1}$ of soil, and for kudzu (Pueraria labata), velvetbean (Mucuna deeringiana) or pine bark (Pinus spp.) $0,2.5,5,7.5,10,15$, $20,25,30$, and $35 \mathrm{~g} \mathrm{~kg}^{-1}$ of soil] on disease severity, 80 days after transplanting of tomato (Lycopersicon esculentum) plants cv. Rutgers in soil infested with Sclerotium rolfsii (average of two plantings). *Significance at $5.0 \%$ on regression analyses. $\mathrm{B}=$ benzaldehyde, $\mathrm{K}=$ kudzu, $\mathrm{V}=$ velvetbean, and $\mathrm{P}=$ pine bark). chitinolytic microorganisms. Hadar \& Gorodecki (1991) found an inhibitory effect of grape marc compost on sclerotial germination and viability, and associated this effect with high numbers of Penicillium isolated from sclerotia.

In our studies, the most common fungi growing on the surface of sclerotia were Trichoderma spp. (mainly T. harzianum Rifai) and occasionally Gliocladium virens Miller et al. (Figure 1I). Mukherjee et al. (1995) compared one isolate of G. virens and one isolate of T. harzianum in relation to their antagonistic properties on Rhizoctonia solani Kühn and S. rolfsii. These authors concluded that only $T$. harzianum parasitized the hyphae of $S$. rolfsii, and both parasitized the hyphae of $R$. solani. Both antagonists were equally comparable in terms of antibiosis, and $G$. virens was most aggressive in destroying sclerotia of $S$. rolfsii (Mukherjee et al., 1995).

Lack of stimulation in formation of new sclerotia in treatments with kudzu or velvetbean might be associated with the presence of antagonists in the case of kudzu and the lowest rate of velvetbean, or with toxicity in the case of high rates of velvet bean. Liberation of toxic or fungistatic compounds could be associated with reduced formation of sclerotia in soil with kudzu and mucuna. Pine bark developed more new sclerotia than kudzu and velvetbean, but less than the non-treated control. However, benzaldehyde generally induced formation of significantly more sclerotia than the non-amended control. Nevertheless, the high numbers of sclerotia formed in response to high rates of benzaldehyde could be associated with an inducing effect of this volatile aromatic compound for hyphal tip curling and hyphal agglomeration, as well as reduction on hyphal growth. These are important phases in sclerotial formation (Zarini \& Christias, 1997).

Our results indicated that there is an optimal period of 
Effect of soil organic amendments on sclerotial germination, mycelial growth...

time for planting after soil amendment. If sowing is implemented too soon after, application of amendments there can be a problem. Soybean germination in treatments with velvet bean and pine bark was low when sowing occurred prior to 20 days after application of the amendments in soil. A phytotoxic effect was noticed when these amendments were applied in high rates $\left(>25 \mathrm{~g} \mathrm{~kg}^{-1}\right)$ and planting made prior to 20 days after application of the soil amendments. On the other hand, amendments increased the number of plants when planting was done 40 days after application of soil amendments (Figure 2B). Not only should rates of amendments be investigated but also when sowing or planting should be carried out. This might explain, in part, why some soil amendments work in one situation and do not work in another. Mian \& Rodríguez-Kábana (1982) reported the phytotoxic effect of kudzu $\left(100 \mathrm{~g} \mathrm{~kg}^{-1}\right)$ in terms of the reduction of germination of squash (Cucurbita pepo L.) seeds, and reported that at $1 \%(10 \mathrm{~g} / \mathrm{kg}) \mathrm{kudzu}$ hay was not toxic to the plant and reduced severity of disease on squash caused by Meloidogyne arenaria (Neal) Chitwood. Most organic amendments are initially detrimental to plants at rates over 5\% $\left(50 \mathrm{~g} \mathrm{~kg}^{-1}\right)$ or when their C: $\mathrm{N}$ ratio is lower than 12 (Rodríguez-Kábana et al., 1987). The best plant development was found when planting was done 40 days after the application of the amendments, this might also be associated with the availability of nutrients for the plants due to the decomposition of kudzu and velvetbean.

Pine bark amended soil generally has reduced disease incidence or severity and increased plant emergence. KokalisBurelle \& Rodríguez-Kábana (1994) reported that fresh or composted pine bark at a rate of $100 \mathrm{~g} \mathrm{~kg}^{-1}$ improved the emergence of lentil (Lens culinaris Medik.) in soil infested with $R$. solani or $S$. rolfsii. Also, these authors correlated the improvement of seedlings emergence with the increased numbers of Penicillium chrysogenum Thom isolated from soils treated with pine bark.

Soil catalase and FDA activities increased positively with the rate of kudzu, velvet bean or pine bark added to soil, reflecting increased microbial activity. Previous studies showed positive correlation between amendments and microbial activity (Kokalis-Burelle \& Rodríguez-Kábana, 1994; SolerSerratosa et al., 1996).

Results from this study indicate that organic amendments can be used to manage $S$. rolfsii and disease caused by this pathogen. The mode of action of these amendments against the pathogen is complex and unknown. Certainly stimulation of microbial activities, determined by physical and chemical properties of materials used for amendments has an important role. Each amendment was associated with an optimal rate to decrease disease incidence and severity, and increase plant survival and growth.

\section{LITERATURE CITED}

BEUTE, M.K. \& RODRÍGUEZ-KÁBANA, R. Effect of volatile compounds from remoistened plant tissues on growth and germination of sclerotia of Sclerotium rolfsii. Phytopathology 69:802-805. 1979.
BEUTE, M.K. \& RODRÍGUEZ-KÁBANA, R. Effects of soil moisture, temperature, and field environment on survival of Sclerotium rolfsii in Alabama and North Carolina. Phytopathology 71:12931296. 1981.

CANULLO, G.H., RODRÍGUEZ-KÁBANA, R. \& KLOEPPER, J.W. Changes in the populations of microorganisms associated with the application of soil amendments to control Sclerotium rolfsii Sacc. Plant and Soil 144:59-66. 1992.

CHET, I. Ultrastructural basis of sclerotial survival in soil. Microbial Ecology 2:194-200. 1975.

FLOR, H.H. Fungicidal activity of furfural. Iowa State College Journal of Science 1:199-227. 1926.

GAMLIEL, A., GRINSTEIN, A. \& KATAN, J. Improved technologies to reduce emission of methyl bromide from fumigated soil. Phytoparasitica 25:21-30. 1997.

GAMLIEL, A. \& STAPLETON, J.J. Characterization of antifungal volatile compounds evolved from solarized soil amended with cabbage residues. Phytopathology 83:899-905. 1993.

HADAR, Y. \& GORODECKI, B. Suppression of germination of sclerotia of Sclerotium rolfsii in compost. Soil Biology and Biochemistry 23:303-306. 1991.

KOKALIS-BURELLE, N. \& RODRÍGUEZ-KÁBANA, R. Changes in populations of soil microorganisms, nematodes, and enzyme activity associated with application of powdered pine bark. Plant and Soil 162:169-175. 1994.

LINDERMAN, R.G. Organic amendments and soilborne diseases. Canadian Journal of Plant Pathology 11:180-183. 1989.

MAITI, D. \& SEN, C. Effect of moisture and temperature on the survival of sclerotia of Sclerotium rolfsii in soil. Journal Phytopathology 121:175-180. 1988.

McLEAN, E.O. Soil pH and lime requirement. In. Page, A.L., Miller, R.H. \& Keeney, D.R. (Eds.) Methods of soil analysis - part 2. Chemical and microbiological properties. $2^{\text {nd }}$. ed. American Society of Agronomy Inc. Madison, Wisconsin, USA. 1982. pp.199-224.

MIAN, I.H. \& RODRÍGUEZ-KÁBANA, R. Survey of the nematicidal properties of some organic materials available in Alabama as amendments to soil for control of Meloidogyne arenaria. Nematropica 12:235-246. 1982.

MUKHERJEE, P.K., MUKHOPADHYAY, A.N., SARMAH, D.K. \& SHRESTHA, S.M. Comparative antagonistic properties of Gliocladium virens and Trichoderma harzianum on Sclerotium rolfsii and Rhizoctonia solani - its relevance to understanding the mechanisms of biocontrol. Journal Phytopathology 143:275-279. 1995.

PUNJA, Z.K. The biology, ecology and control of Sclerotium rolfsii. Annual Review of Phytopathology 23:97-127. 1985.

PUNJA, Z.K. \& RAHE, J.E. Sclerotium. In: Singleton, L.L., Mihail, J.D. \& Rush, C.M. (Eds.) Methods for research on soilborne phytopathogenic fungi. APS Press, St. Paul, MN. 1992. pp.166-170.

RHOADES, J.D. Soluble salts. In. Page, A.L., Miller, R.H. \& Keeney, D.R. (Eds.). Methods of soil analysis. Part 2. Chemical and microbiological properties. 2nd. Ed. American Society of Agronomy Inc. Madison, Wisconsin, USA. 1982. pp.167-179.

RODRÍGUEZ-KÁBANA, R., BACKMAN, P.A. \& McLEOD, C. A soil plate method for rapid screening of pesticides against Sclerotium rolfsii. Plant Disease 59:439-442. 1975a.

RODRÍGUEZ-KÁBANA, R., MORGAN-JONES, G. \& CHET, I. Biological control of nematodes: soil amendments and microbial 
antagonists. Plant and Soil 100:237-247. 1987.

RODRÍGUEZ-KÁBANA, R., PINOCHET, J., ROBERTSON, D.G. $\&$ WELLS, L. Crop rotation studies with velvetbean (Mucuna deeringiana) for the management of Meloidogyne spp. Journal of Nematology 24:662-668. 1992. (Supplement)

RODRÍGUEZ-KÁBANA, R. \& TRUELOVE, B. The determination of soil catalase activity. Enzymologia 39:217-236. 1970.

SCHNURER, J. \& ROSSWALL, T. Fluorescein diacetate hydrolysis as a measure of total microbial activity in soil and litter. Applied Environmental Microbiology 43:1256-1261. 1982.
SMITH, A.M. Drying and wetting sclerotia promotes biological control of Sclerotium rolfsii. Soil Biology and Biochemistry 4:119123. 1972.

SOLER-SERRATOSA, A., KOKALIS-BURELLE, N., RODRÍGUEZ-KÁBANA, R., WEAVER, C.F. \& KING, P.S. Allelochemicals for control of plant-parasitic nematodes. Nematropica 26:57-71. 1996

ZARINI, F. \& CHRISTIAS, C. Sclerotial biogenesis in the basidiomycete Sclerotium rolfsii - A scanning electron microscope study. Mycologia 89:598-602. 1997. 